\title{
Wild versus head-started hawksbill turtles Eretmochelys imbricata: post-release behavior and feeding adaptions
}

\author{
Junichi Okuyama ${ }^{1, *}$, Tomohito Shimizu ${ }^{2,4}$, Osamu Abe ${ }^{3,5}, K_{\text {Kenzo Yoseda }}^{2,6}$, \\ Nobuaki Arai ${ }^{1}$ \\ ${ }^{1}$ Graduate School of Informatics, Kyoto University, Yoshida Honmachi, Sakyo-ku, Kyoto, 606-8501, Japan \\ ${ }^{2}$ Yaeyama Station, National Center for Stock Enhancement, Fisheries Research Agency, Fukaiohta 148, Ishigaki, \\ Okinawa 907-0451, Japan \\ ${ }^{3}$ Ishigaki Tropical Station, Seikai National Fisheries Research Institute, Fisheries Research Agency, Fukaiohta 148-446, \\ Ishigaki, Okinawa 907-0451, Japan \\ ${ }^{4}$ Present address: Management Section, National Center for Stock Enhancement, Headquarters, Fisheries Research Agency, \\ Queen's Tower B 15F, 2-3-3, Minatomirai, Nishi-ku, Yokohama, Kanagawa, 220-6115, Japan \\ ${ }^{5}$ Present address: Marine Fishery Resources Development and Management Department, Southeast Asian Fisheries \\ Development Center, Taman Perikanan, Chendering 21080 Kuala Terengganu, Malaysia \\ ${ }^{6}$ Present address: Ishigaki Tropical Station, Seikai National Fisheries Research Institute, Fisheries Research Agency, \\ Fukaiohta 148-446, Ishigaki, Okinawa 907-0451, Japan
}

\begin{abstract}
To ensure the success of reintroduction programs, it is important to monitor the postrelease behavior and survival of released animals. In this study, the post-release movement and behavior of 5 wild and 5 head-started hawksbill turtles Eretmochelys imbricata were monitored using ultrasonic telemetry. Their dispersal directions and recaptures may indicate that wild turtles perform homing migrations. However, the head-started turtles showed non-uniform patterns in dispersal movements. Four head-started turtles moved out of the monitoring area in various directions, whereas one turtle stayed within the monitoring area for approx. 10 mo. These results might indicate that head-started turtles wander aimlessly in their new surroundings. Signal reception patterns indicated that wild turtles were active in the daytime and rested under the coral at night. Although the head-started turtles also rest at night, their resting places did not seem to be sheltered from hazardous sea conditions or adequate for efficient resting. Therefore, head-started hawksbill turtles appear to need pre-release training such as exposure to structures or ledges in the rearing tank so they can utilize similar structures in the wild for shelter during rest periods and maximize their dive duration by employing these as a roof to counteract the positive buoyant effect of inhaled air. Prey analysis of a head-started turtle captured incidentally demonstrates that these turtles can make feeding adaptations to adjust to the natural environment. These findings provide constructive information for the implementation and improvement of head-start programs.
\end{abstract}

KEY WORDS: Conservation - Eretmochelys imbricata · Feeding adaptation · Head-starting Reintroduction · Ultrasonic telemetry

\section{INTRODUCTION}

Reintroduction with captive breeding and release programs have become important conservation measures for the recovery of threatened and endangered species around the world (Beck et al. 1994, Wilson \& Price 1994, IUCN 1998, Stanley Price \& Soorae 2003, Seddon et al. 2007). However, many reintroduction programs for captive-born animals are still not well organized, and improvements are necessary before they can be 
successful (Beck et al. 1994, Stanley Price \& Soorae 2003, Seddon et al. 2007). In order for released animals to survive in the wild, the animals have to be able to find and process food, avoid predators, interact appropriately with conspecifics, find and construct shelters, and orient and navigate in complex environments (Kleiman 1989, Beck et al. 1994, IUCN 1998). Consequently, to ensure the success of reintroduction programs, it is important to conduct post-release monitoring of the behavior and survival of released animals, such as the mortality rate, cause of mortality, reproduction rate, and home range, as such data can provide information on the quality of animals for release and can also contribute to and/or improve reintroduction programs (Beck et al. 1994, IUCN 1998). The translocation of exclusively wild-caught animals is more likely to succeed than that of exclusively captive-born animals (Griffith et al. 1989), implying that experience of living in wild habitats enhances the survival probability of released animals. When captive-born animals are used in reintroduction programs, therefore, released animals are assumed to behave and survive in the same way as wild animals (Beck et al. 1994, IUCN 1998). Thus, it is also necessary to know behavioral features such as movements, home ranges, habitat selection, and survival behaviors of free-ranging, wildborn animals (Kleiman 1989, IUCN 1998).

Sea turtles are well-recognized marine reptiles that are known to be endangered worldwide. In an attempt at population recovery of sea turtles, head-starting, which is a type of reintroduction program, has been conducted at various locations throughout the world (e.g. Huff 1989, Sato \& Madriasau 1991, Bell et al. 2005, Fontaine \& Shaver 2005). Head-starting is the practice of growing hatchlings in captivity to a size that protects them from the high rates of natural predation that would have otherwise occurred in their early months, and then releasing them into the sea (Klima \& McVey 1995, Mortimer 1995, Shaver \& Wibbels 2007). However, the effectiveness of head-starting has been unproven due to a lack of data regarding the survival, adaptation, and eventual breeding of the turtles following their release (Shaver \& Wibbels 2007). Therefore, close monitoring of the behavior, survival, and adaptation processes of post-release turtles and the accumulation of such data are important for evaluating head-starting, although many controversies and concerns regarding head-starting have been expressed (Shaver \& Wibbels 2007).

In the present study, we closely monitored the behavior and dispersal process of head-started hawksbill turtles Eretmochelys imbricata in order to determine how the head-started turtles behaved compared to those in the wild. We also monitored the behavior of wild hawksbill turtles for comparison purposes. In the present study, we employed ultrasonic telemetry to track the turtles after their release. The purpose of this study was to increase knowledge of the post-release behavior and the survival and feeding capabilities of head-started hawksbill turtles, and to suggest improvements to methods used to rear turtles before release.

\section{MATERIALS AND METHODS}

Study area and experimental animals. This study was conducted on the north part of Ishigaki Island, which is one of the Yaeyama Islands located in the southwestern part of Japan (Fig. 1a). Immature hawksbill turtles with straight carapace lengths (SCL) of 39.3 to $63.1 \mathrm{~cm}$ have been reported in the Yaeyama Islands (Kamezaki \& Hirate 1992). Yaeyama Station, part of the National Center for Stock Enhancement (NCSE), Fisheries Agency, Japan, is located on Ishigaki Island. It has successfully obtained hatchlings from long-term captive brood and has been running an experimental head-start program of captive-reared turtles for stock enhancement since 2003 (Yoseda \& Shimizu 2006).

Five wild and 5 head-started hawksbill turtles were used in this study. Wild and head-started turtles had similar SCL and body weights (BW), and neither SCL nor BW were significantly different between the 2 groups according to $t$-tests $(t=1.74, \mathrm{p}>0.05$, for SCL; $t=1.33, \mathrm{p}>0.05$, for $\mathrm{BW}$; Table 1). The wild turtles were caught at different locations on the Yaeyama Islands with the permission of the Okinawa Prefecture (Permission No. 16-19) (Fig. 1). The captured turtles were of sizes common in the Yaeyama Islands (Table 1). The captured wild turtles were maintained in the 2 or $5 \mathrm{kl}$ rearing tanks at Yaeyama station for about 4 mo before the start of the experiment. The head-started turtles were reared from eggs for $2.5 \mathrm{yr}$ at the Yaeyama station. The eggs used in this study were laid on east Hirakubo beach in the northern part of Ishigaki Island (Fig. 1a). Fifty eggs were translocated to the Yaeyama station and then hatched in incubators at a temperature of about $29^{\circ} \mathrm{C}$ with huidity exceeding $90 \%$. After hatching, the turtles were reared in the $60 \mathrm{l}$ tank. We then changed the size of the rearing tanks as the turtles grew (up to age 2 mo: $200 l_{\text {i }}$ from age 2 mo: 2 or $5 \mathrm{kl}$; yearlings: $15 \mathrm{kl}$ tanks). Each tank housed 10 to 20 turtles. These turtles did not experience an imprinting procedure which allowed them to crawl down to the beach and enter the surf when they hatched as in a previous head-start project with Kemp's ridley turtles (see Shaver 2005). The rearing tanks were placed in a building with sunroofs and windows. Therefore, the photoperiod in the rearing houses shifted naturally. The seawater in the rearing tanks was pumped up 
Table 1. Eretmochelys imbricata. Summary of physical and experimental data on the turtles. SCL: straight carapace length; BW: body weight

\begin{tabular}{|c|c|c|c|c|c|c|}
\hline Turtle ID & $\mathrm{SCL}(\mathrm{cm})$ & BW (kg) & Depth sensor & $\begin{array}{l}\text { Last detection } \\
\text { (dd/mm/yy) }\end{array}$ & Days of data & Recapture \\
\hline \multicolumn{7}{|c|}{ Wild turtles } \\
\hline WH1 & 37.0 & 4.5 & Yes & 20/04/05 & 2 & Yes (182 d later) \\
\hline WH2 & 47.0 & 9.5 & Yes & $21 / 04 / 05$ & 3 & Yes (199 d later) \\
\hline WH3 & 48.6 & 11.6 & Yes & $27 / 04 / 05$ & 8 & No \\
\hline WH4 & 43.3 & 8.4 & Yes & $23 / 04 / 05$ & 4 & No \\
\hline WH5 & 43.3 & 6.7 & No & $26 / 04 / 05$ & 7 & No \\
\hline \multicolumn{7}{|c|}{ Head-started turtles } \\
\hline HH1 & 39.6 & 6.6 & Yes & $22 / 04 / 05$ & 4 & No \\
\hline $\mathrm{HH} 2$ & 42.0 & 7.8 & Yes & $22 / 04 / 05$ & 4 & No \\
\hline HН3 & 40.2 & 7.2 & Yes & 02/05/05 & 8 & No \\
\hline $\mathrm{HH} 4$ & 41.2 & 7.0 & Yes & $15 / 07 / 05+02 / 02 / 06^{a}$ & $77+29^{a}$ & Yes (88 d later) \\
\hline HH5 & 44.0 & 8.4 & No & $10 / 06 / 05$ & 9 & No \\
\hline
\end{tabular}

from the sea in front of the Yaeyama station. Five healthy-looking turtles were selected from the reared turtles as experimental individuals. Both the wild and the head-started turtles were fed on the pellet mixed
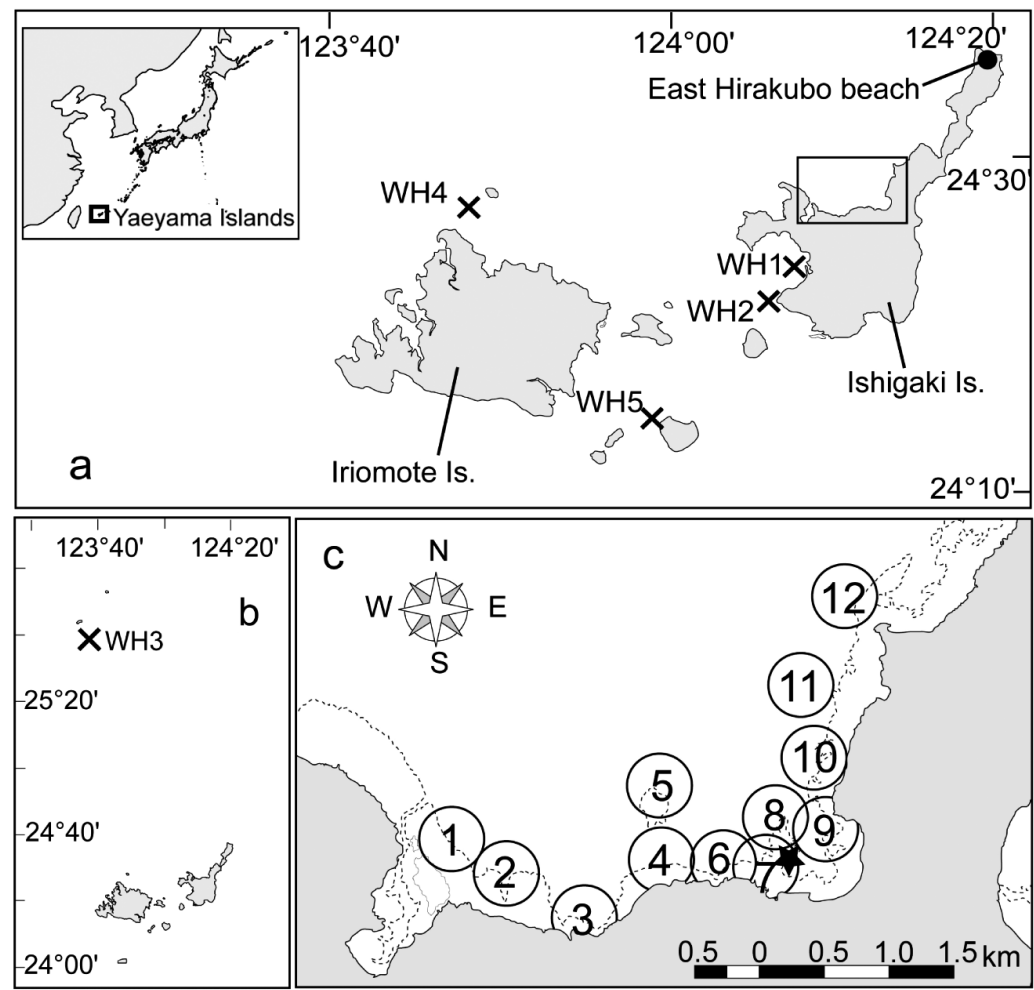

Fig. 1. Eretmochelys imbricata. Study site. $(\mathrm{a}, \mathrm{b})$ Yaeyama Islands and capture points of wild turtles (WH). Crosses: capture points; black rectangle: experimental area. (c) Release point of the experimental turtles and the monitoring area. Black star: release point; circles: location of receivers (1 to 12) and their expected detection ranges, $500 \mathrm{~m}$ in radius. Dotted line: reef edge with fishmeal and vitamins twice a day, in the morning and early evening. The daily amount of feed was 2 to $3 \%$ of each turtle's weight. During rearing, the headstarted turtles approached humans around the tanks in contrast to the wild turtles, which did not approach humans. The wild turtles instead were often still and stayed in the corners of the tank.

Experimental protocol and tracking method. We employed ultrasonic telemetry to monitor the behavior of the turtles. The turtles were fitted with a transmitter, either model V16P-6H (diameter: $16 \mathrm{~mm}$; length: $106 \mathrm{~mm}$; weight: $16 \mathrm{~g}$ in water; approximately $853 \mathrm{~d}$ of battery life; Vemco) or V16-6H (diameter: $16 \mathrm{~mm}$; length: $90 \mathrm{~mm}$; weight: $14 \mathrm{~g}$ in water; approximately $876 \mathrm{~d}$ of battery life) which were attached to the center of carapace using epoxy putty (Konishi) and 2-component epoxy resin (ITW Industry). The turtles were also marked with plastic, metal and passive integrated transponder (PIT) tags. The transmitters were coded with a unique pulse series for each turtle and transmitted signals at randomly spaced intervals of between 5 and 30 s. The V16P-6H transmitters were equipped with built-in depth sensors (Table 1). Ultrasonic transmissions were 69.0 Hz, which is known to be outside the hearing capacity of green turtles Chelonia mydas (30 to $1000 \mathrm{~Hz}$, Ridgway et al. 1969) and juvenile loggerhead turtles Caretta caretta (250 to $1000 \mathrm{~Hz}$, Bartol et 
al. 1999), although the hearing capacity of hawksbill turtles has not been investigated. Previous studies using ultrasonic transmitters did not report behavioral inhibition caused by ultrasonic waves or transmitter attachment (Brill et al. 1995, Seminoff et al. 2002, Blumenthal et al. 2009). Therefore, we believe that the ultrasonic telemetry did not affect the behavior of the hawksbill turtles in this study.

All of the turtles were released from the release point $\left(24^{\circ} 28^{\prime} 06.84^{\prime} \mathrm{N}, 124^{\circ} 12^{\prime} 42.26^{\prime} \mathrm{E}\right.$, Fig. 1c) at the same time on 19 April 2005 after $1 \mathrm{~h}$ sea-acclimation in an enclosure net $(\mathrm{L} \times \mathrm{W} \times \mathrm{H}=4 \times 4 \times 5 \mathrm{~m})$. Twelve fixed receiver monitoring systems (VR2, Vemco) were used. The receivers were deployed on the sea floor at about $18 \mathrm{~m}$ depth along the reef edge on the north side of Ishigaki Island (Fig.1c). Turtle identification, depth, date, and time were recorded when the turtles came within the detection range, which was expected to be about $500 \mathrm{~m}$ in radius. The monitoring period was from 19 April 2005 to 3 March 2006.

Because Turtle HH4 was hand-captured by a local fisherman who was fishing underwater on 15 July 2005, we re-released it at the point of capture on 26 July after determining its growth rate and prey items it had consumed in the natural environment. This re-release was defined as the second release of Turtle HH4. We also measured the growth rates of Turtles WH1 and WH2, which were recaptured on 24 October 2005 and 10 November 2005, respectively, and then re-released them from their respective recapture points.

Prey sample collection and identification. Turtle HH4, which had been captured incredentally, was measured and then kept in a tank at Yaeyama Station. While the turtle was in captivity, its discharged droppings were sampled to investigate the diets of headstarted turtles in a natural environment. The wet mass and weight of samples were measured and then preserved in $100 \%$ ethanol solution, after which the samples were identified.

Data analysis. Signals from the turtles were generally received by several receivers per day, reflecting the migration routes of the turtles. Thus, the daily location of the turtles was defined as the location of the receiver detecting the maximum number of signals from each turtle during a day. In order to compare the number of signal receptions between diurnal and nocturnal periods, we defined the diurnal period as the time between 05:00 and 18:59 $\mathrm{h}$ and the nocturnal period as the time between 19:00 and 04:59 $\mathrm{h}$, based on the approximate times of sunset and sunrise during the experiment.

Because signal receptions from the turtles were not continuous, time-series analyses for data reception patterns and dive depths were difficult to construct. Therefore, data collected over a $1 \mathrm{~h}$ period were de- fined as a data unit. For the analysis of data reception patterns, the data were treated as binary data, that is, presence or absence during a $1 \mathrm{~h}$ period. Turtles were defined as being present during a period if signals were received at least once during an hour-long period. For the analysis of diving depth, mean dive depth over a $1 \mathrm{~h}$ period was defined from the dive depth data during that period.

Wilcoxon signed-ranks tests for paired comparisons were used to determine whether turtle signal receptions differed between diurnal and nocturnal periods. Differences in signal receptions between wild and head-started turtles during each period were determined using Mann-Whitney $U$-tests. Mann-Whitney $U$ tests were also employed to detect differences in dive depth between wild and head-started turtles, and between diurnal and nocturnal periods. P-values of less than 0.05 were considered to be statistically significant.

The behavioral data gathered after the re-released Turtle HH4 were omitted from the behavioral comparisons between wild and head-started turtles due to the differences in the times of release and the the turtle's previous experience of having lived in the sea. In order to determine the time-series changes in diel patterns of signal receptions and dive depths, we divided the monitoring period into 5 time periods; Period 1 (19 April-18 May 2005, days of data $=26$ ); Period 2 (19 May-18 June 2005, days of data $=25$ ); Period 3 (19 June-15 July 2005 [date of capture], days of data = 24); Period 4 (26 July [date of second release]- $24 \mathrm{Au}$ gust 2005, days of data $=17$ ); and Period 5 (4 February-3 March 2006 [date that the fixed receivers were retrieved], days of data $=12$ ). Kruskal-Wallis tests were used to determine whether signal receptions or dive depths changed significantly throughout the 5 time periods. We employed Wilcoxon signed-ranks tests for paired comparisons to determine whether differences in signal reception patterns existed between diurnal and nocturnal periods over the 5 time periods.

\section{RESULTS}

\section{General results}

The wild hawksbill turtles were tracked for a mean of $5.4 \pm 3.0 \mathrm{~d}$, whereas the head-started turtles were tracked for $32.6 \pm 37.0 \mathrm{~d}$ (Table 1). During the tracking period, post-release data were obtained for $4.8 \pm 2.6 \mathrm{~d}$ for the wild turtles and for $20.4 \pm 31.7 \mathrm{~d}$ for the headstarted turtles (Table 1, Fig. 2). No significant differences were found in tracking periods and days of data between wild and head-started turtles (Mann-Whitney $U$-test, $Z=0.86, \mathrm{p}=0.39$ for tracking period, $Z=1.48$, $\mathrm{p}=0.14$ for days of data). 
Four of the 5 wild turtles (WH1, WH2, WH4, and WH5) moved west, and the other one (WH3) moved north along the reef edge (Fig. 2a). Assuming that the directions of their migration pathways were primarily north and west, parallel to the reef edge, wild-caught turtles tended to return to the place where they had

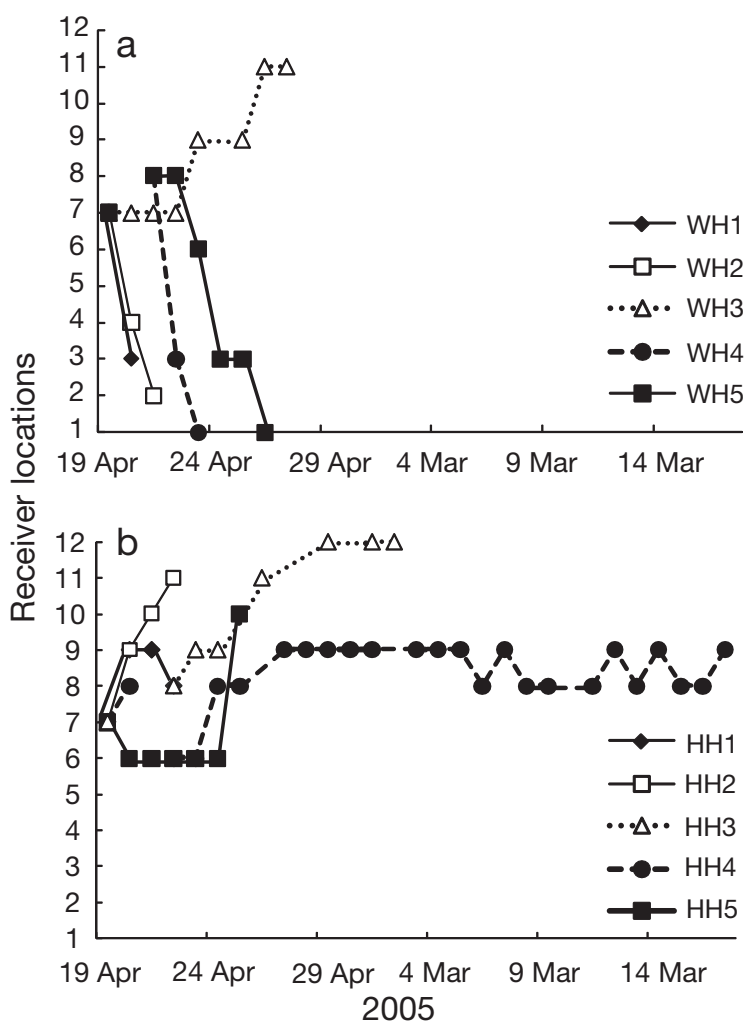

Fig. 2. Eretmochelys imbricata. Post-release horizontal movements of (a) wild $(\mathrm{WH})$, and (b) head-started $(\mathrm{HH})$ turtles for the initial 4 wk (19 April-16 May 2005). Symbols plotted on the days data were obtained been captured before the experiment (binomial test, $\mathrm{p}<0.05)$. In fact, Turtles WH1 and WH2 were recaptured at the locations where they initially had been captured 182 and 199 d after the release, respectively. During the periods between release and recapture, the growth rates of these turtles were $3.9 \mathrm{~cm}$ in SCL and $1.6 \mathrm{~kg}$ in BW for WH1 and $1.9 \mathrm{~cm}$ in SCL and $2.0 \mathrm{~kg}$ in BW for WH2.

The head-started turtles showed different movement patterns (Fig.2b). Four of the 5 head-started turtles (HH1, HH2, HH3, and HH5) moved out of the monitoring area in 2 to14 d. Turtles HH2, HH3, and HH5 moved northward, and the signals from Turtle HH1 were lost in the middle of the monitoring area. Turtle HH5 re-entered the monitoring area $34 \mathrm{~d}$ after its disappearance from that area and then moved westward in $2 \mathrm{~d}$. However, one turtle (HH4) stayed around the release point and adjacent area for $88 \mathrm{~d}$, growing $1 \mathrm{~cm}$ in SCL and $0.11 \mathrm{~kg}$ in BW, until it was captured incidentally. The diet composition of Turtle HH4 included 8 pieces (total wet wt $13.4 \mathrm{~g}$ ) of demosponges Chondrosia sp. and a thin piece of plastic (0.27 $\mathrm{g}$ wet wt).

\section{Diel patterns in signal reception}

The mean signal receptions per hour from wild and head-started turtles were calculated. Signal receptions from the wild turtles were concentrated during the diurnal period (05:00 to $18: 59 \mathrm{~h}$ ) and were very rare during the nocturnal period (19:00 to 04:59 h) (Fig. 3a). A significant difference in signal reception was found between diurnal and nocturnal periods (Wilcoxon test, $Z=2.02, \mathrm{p}<0.05)$. Conversely, all of the head-started turtles were detected many times, with, like wild tur-

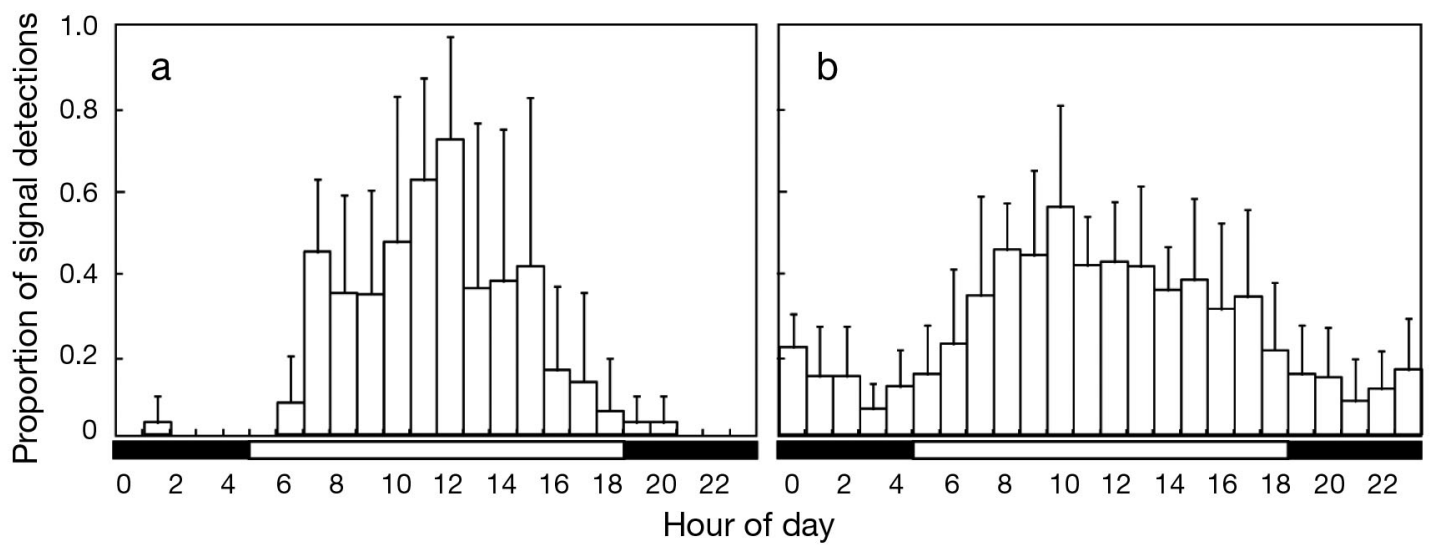

Fig. 3. Eretmochelys imbricata. Signal reception patterns of (a) wild and (b) head-started turtles during a day. Black and white zones show the nocturnal and diurnal periods, respectively. Vertical bars represent the mean proportion (+SD) of hourly signal detections 
tles, significantly more data receptions during the diurnal period (Wilcoxon test, $Z=2.02$, $\mathrm{p}<0.05$ ) but with nocturnal receptions also being detected (Fig. 3b). During the nocturnal period, significantly more signals were received, on average, from head-started turtles than from wild turtles (Mann-Whitney $U$-test, $Z=2.48$, $\mathrm{p}<0.05$ ), whereas during the diurnal period, no significant difference was found between receptions from wild and head-started turtles (Mann-Whitney $U$-test, $Z=0.31, \mathrm{p}=0.75$ ).

\section{Dive depth}

The dive depths of 4 wild and 4 head-started turtles are summarized in Table 2 . The nocturnal dive depths of one head-started (HH1) and 3 wild (WH1, 2, and 4) turtles could not be obtained due to a lack of signal receptions. The mean dive depths of the wild turtles during the diurnal and nocturnal periods were $7.3 \pm 3.1 \mathrm{~m}$ (mean $\pm \mathrm{SD}$ ) and $2.1 \mathrm{~m}$, respectively, and those of the head-started turtles were $8.5 \pm 1.8 \mathrm{~m}$ and $9.5 \pm 2.1 \mathrm{~m}$, respectively. The head-started turtles did not change their dive depth significantly between diurnal and nocturnal periods (Mann-Whitney $U$-test, $Z=0.71, \mathrm{p}=0.25$ ). No significant difference was observed in dive depth between wild and head-started turtles during the diurnal period (Mann-Whitney $U$-test, $Z=1.15, \mathrm{p}=0.48$ ).

During the diurnal period, signals from wild turtles were recorded at various depth zones, although the signals were not recorded continuously, indicating vertical movements of the wild turtles during the diurnal period (Fig. 4a). Similarly, signals from head-started turtles were also recorded at various depth zones in the diurnal periods (Fig.4b), whereas signals during nocturnal periods were almost all recorded at constant depth zones, indicating an absence of vertical movement during the nocturnal period (Fig.4c).

Table 2. Eretmochelys imbricata. Dive data (mean $\pm \mathrm{SD})$ from diurnal and nocturnal periods

\begin{tabular}{|lcccc|}
\hline \multirow{2}{*}{ Turtle ID } & \multicolumn{2}{c}{ Diurnal period } & \multicolumn{2}{c|}{ Nocturnal period } \\
& Depth $(\mathrm{m})$ & $\mathrm{N}$ & Depth $(\mathrm{m})$ & $\mathrm{N}$ \\
\hline Wild turtles & & & & \\
WH1 & $11.9 \pm 4.2$ & 13 & - & 0 \\
WH2 & $5.5 \pm 2.2$ & 10 & - & 0 \\
WH3 & $5.7 \pm 3.3$ & 20 & $2.1 \pm 0.6$ & 3 \\
WH4 & $6.0 \pm 4.2$ & 14 & - & 0 \\
& & & & \\
Head-started turtles & & & - & 0 \\
HH1 & $7.3 \pm 6.3$ & 17 & $8.1 \pm 1.5$ & 9 \\
HH2 & $6.9 \pm 3.4$ & 22 & $11.9 \pm 2.7$ & 12 \\
HH3 & $10.9 \pm 2.6$ & 39 & $8.4 \pm 0.2$ & 57 \\
HH4 & $8.9 \pm 0.9$ & 299 & & \\
\hline
\end{tabular}
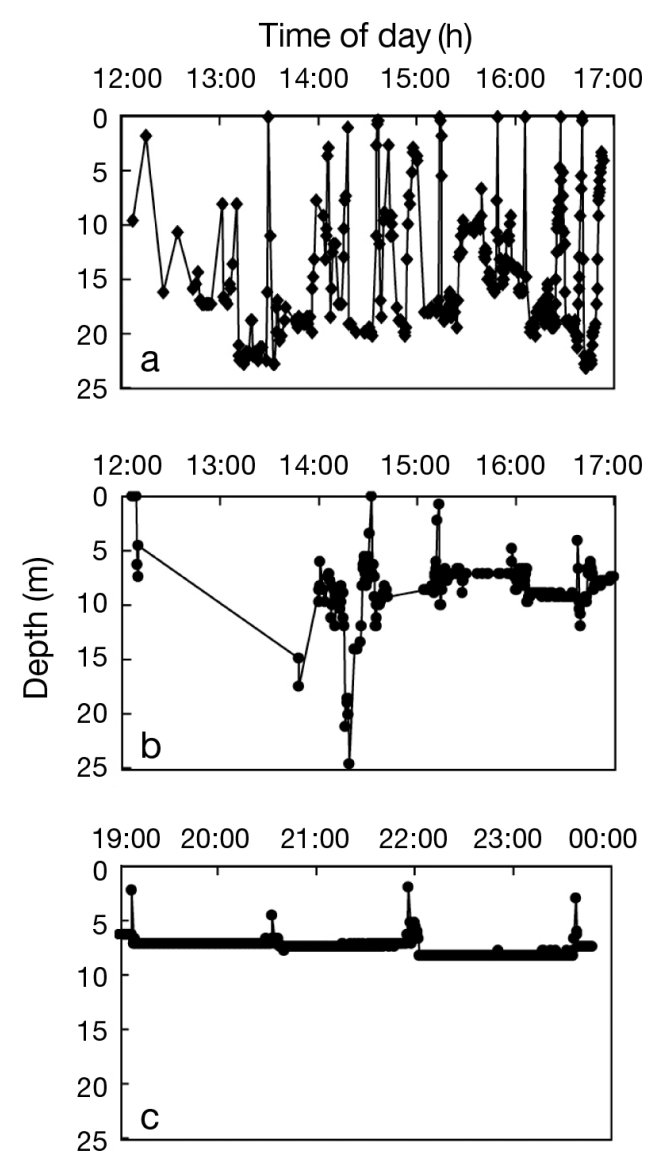

Fig. 4. Eretmochelys imbricata. Typical diving profiles of (a) a wild turtle (WH1) during the diurnal period (12:00-17:00 h) and a head-started turtle (HH2) during (b) diurnal (12:0017:00 h) and (c) nocturnal (19:00-00:00 h) periods

\section{Behavior and signal reception patterns of Turtle HH4 after the second release}

Turtle HH4 was detected intermittently within the monitoring area until 3 March 2006 (220 d after the second release), when the fixed receivers were retrieved. The habitat utilization of turtle HH4 after the second release (Periods 4 and 5) was wider compared to that recorded from after the first release (Periods 1 to 3 ) (Fig. 5a). The utilized habitat often shifted westward and northward from the second release point. The mean dive depths changed significantly among the 5 time periods (Kruskal-Wallis test, $H=54.3, \mathrm{p}<0.01$ ) (Fig. 5a). Significantly more signal receptions were received in diurnal periods than in nocturnal periods during the 5 time periods (Wilcoxon test, $Z=2.02, \mathrm{p}<0.05$ ) (Fig. 5b). Throughout the 5 time periods, the signal receptions from both diurnal and nocturnal periods significantly changed (Kruskal- 

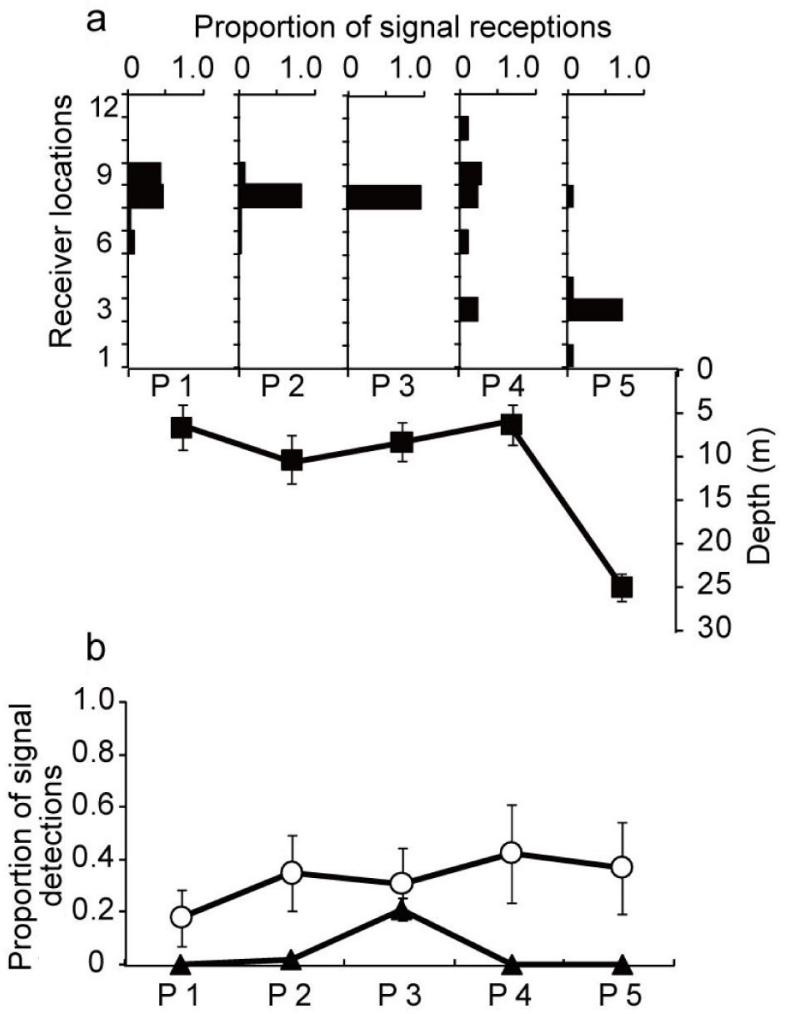

Fig. 5. Eretmochelys imbricata. Time-series variations in (a) horizontal movement and dive depth, and (b) signal detections during diurnal and nocturnal periods from the headstarted turtle (HH4) over 5 time periods (P1 to P5). Mean proportion of signal detections in the diurnal $(\mathrm{O})$ and nocturnal

(ム) periods during each period. Vertical bars are $\pm \mathrm{SD}$

Wallis test, $H=18.9, \mathrm{p}<0.01$ for the diurnal period, $H=36.9, \mathrm{p}<0.01$ for the nocturnal period).

\section{DISCUSSION}

\section{Dispersal patterns}

Avens et al. (2003) reported that juvenile loggerhead sea turtles had site fidelity and returned to their habitat if released in another place. In addition, according to earlier reports, immature hawksbill turtles tend to remain in the same developmental habitat for an extended period (Limpus 1992, van Dam \& Diez 1998, Blumenthal et al. 2009). In the present study, the wild turtles were captured from various locations throughout the Yeayama Islands (Fig. 1). The correspondence of the direction of each turtle's dispersal with its place of capture and the recapture of 2 turtles (WH1 and WH2) at their initial capture location may indicate that the wild turtles performed homing migrations after release. However, previous studies conducted on the
Yaeyama Islands reported that wild juvenile hawksbill turtles undertook some distance migration (Kamezaki 1987, Kamezaki \& Hirate 1992). Therefore, further studies are needed in order to clarify the homing behavior of juvenile hawksbill turtles.

A few previous studies have conducted radiotelemetry tracking of juvenile head-started turtles following release (11 mo old Kemp's ridleys, Wibbels 1984; yearling Kemp's ridleys, Klima \& McVey 1995; 1.5 and $2.5 \mathrm{yr}$ old loggerheads, Nagelkerken et al. 2003). Their results indicated that the turtles exhibited various dispersal directions, with some turtles moving offshore and others moving along the shore. In one study, many of the released turtles were found to have remained relatively close to the release area at the end of the 27 d study period (Wibbels 1984). Additionally, the results of a study by Klima \& McVey (1995) showed that turtles tended to stay in the same area for about $10 \mathrm{~d}$ after their release. In the present study, our results also demonstrated that head-started turtles showed non-uniform patterns of dispersal movement after their release. Four turtles moved out of the monitoring area in various directions, while one turtle stayed within the monitoring area for approx. 10 mo. They did not seem to have a pre-determined destination, as the wild turtles appeared to have. Therefore, our results suggest that head-started turtles might wander aimlessly in their new surroundings. A possibility exists that such aimless wanderings might lead them on long-distance migrations, as has been reported in studies on headstarted Kemp's ridley turtles (Wibbels 1983, Manzella et al. 1988).

\section{Diel behavioral patterns}

Wild juvenile hawksbill turtles are known to be active during diurnal periods and to be inactive and to rest during nocturnal periods in Caribbean habitats (van Dam \& Diez 1996, 1997a, Blumenthal et al. 2009). Many of the signal receptions from various depth zones from the wild turtles in this study (Figs. 3 \& 4a) indicate that the wild turtles on the Yaeyama Islands are also active during diurnal periods. Likewise, during the nocturnal period, signal receptions from wild turtles were rare. While resting, hawksbill turtles are occasionally observed wedged under coral reefs (van Dam \& Diez 1997a, Houghton et al. 2003, Blumenthal et al. 2009, J. Okuyama pers. obs.), possibly in order to use these for shelter (van Dam \& Diez 1997a, Storch et al. 2006) and maximize dive duration by employing these as a roof to counteract the positive buoyant affect of inhaled air (Houghton et al. 2003). The ultrasonic telemetry signals are known to be blocked when the transmitter is surrounded by structures such as rock 
reef and raised corals (Arendt et al. 2001, Mitamura et al. 2005, Yokota et al. 2006, Kawabata et al. 2008). Therefore, the lack of signal receptions during the nocturnal period strongly suggests that wild turtles rest under the coral reef and/or some rocks.

The dive profiles (Fig. 4b) and the signal receptions from head-started turtles, which were as frequent as those from wild turtles (Fig. 3), indicated that the headstarted turtles were also active during the diurnal period. During nocturnal periods, some signals were received from head-started turtles, but most of these signals were transmitted from constant depth zones (Fig. 4c). These results suggest that the head-started turtles were resting during the nocturnal period, but that their resting places were not as surrounded by structures as were those of the wild turtles. This could mean that head-started turtles will be carried away by strong currents under hazardous sea conditions such as a hurricane, or consume unnecessary energy in order to remain in the same place as opposed to wild turtles, which probably take shelter during hurricanes (Storch et al. 2006). In addition, head-started turtles might not maximize their dive duration, because they have positive buoyancy in shallow water when they breathe fully (Houghton et al. 2003). An effect of the rearing conditions and environment, such as the feeding schedule, on the diel behavioral pattern of the head-started turtles after release could not be ruled out from the results of the present study, although no such effects were identified from the analysis of the diel signal reception patterns. Our results suggest that headstarted hawksbill turtles need pre-release training, such as exposure to structures or ledges in the rearing tank, so that they can use similar structures in the wild for shelter during rest periods and maximize their dive duration. The expectation (Beck et al. 1994, IUCN 1998, see 'Introduction') is that released animals will behave in the same way as wild animals.

\section{Dive depths}

Head-started turtles were expected to be poor divers because they had been raised in a very shallow tank measuring about $2 \mathrm{~m}$ in depth. However, the mean dive depths of the head-started turtles were not significantly different from those of wild turtles, indicating that the small space available to them in captivity may not affect the vertical range of their living space after release.

Some wild juvenile hawksbill turtles in Caribbean habitats are known to change their depth utilization between diurnal and nocturnal periods (van Dam \& Diez 1996, Blumenthal et al. 2009), whereas some turtles do not exhibit this change (van Dam \& Diez 1997a). In the present study, the head-started turtles did not change their dive depths between diurnal and nocturnal periods (Table 2). However, from our results, we could not determine whether such unchanging patterns of utilization in vertical living area were normal for wild hawksbill turtles in the Yaeyama Islands because signals were not received from wild turtles during nocturnal periods. Further study is needed on the depth utilization of wild turtles during nocturnal periods in the Yaeyama Islands.

\section{Feeding adaptations of head-started hawksbill turtles}

The post-release diet of head-started turtles is an indicator of their ability to successfully adapt to the wild (Shaver \& Wibbels 2007). Head-started Kemp's ridley turtles were reported to have adaptive ability to feed in the wild (Shaver 1991, Werner \& Landry 1994). However, these are the only reports available on Kemp's ridleys, and no studies have been conducted on other species of head-started turtle. Juvenile hawksbill turtles are known to feed primarily on benthic invertebrates, notably sponges (Meylan 1988, van Dam \& Diez 1997b, León \& Bjorndal 2002). Our result demonstrates that a head-started juvenile hawksbill turtles has the capability to forage for their natural prey, a demosponge Chondrosia sp. The head-started turtle's growth rates of $1 \mathrm{~cm}$ in SCL and $0.11 \mathrm{~kg}$ in BW over $88 \mathrm{~d}$ were similar to the growth rates of wild turtles on the Yaeyama Islands (WH1 and WH2) and in other regions (Limpus 1992, Diez \& van Dam 2002). The turtles reared in captivity on Yaeyama Station are fed on pellet mixed with fishmeal and vitamins from the time of hatching. Therefore, it is very interesting that a head-started turtle without training has the ability to forage natural prey at about 3 mo and to grow normally in its natural environment. This result is an important finding which supports the release of headstarted turtles as a conservation tool.

\section{Behavior of a head-started turtle over ca. 1 yr}

Long-term monitoring provides important information on the survival and environmental adaptation processes of reintroduced animals following release (Kleiman 1989). For post-release monitoring, it is obvious that longer is better, because more information on released animals can be collected over a longer period of time. In this study, a head-started turtle (HH4) was monitored until about 7 mo after its second release, indicating that head-started juvenile hawksbill turtles are able to survive in natural environments for at least 7 mo. 
The signal detection locations and depth utilization patterns of this turtle changed throughout the study periods (Fig. 5a). This indicates that the head-started turtle shifted its habitat with the passage of time. Previous studies on wild juvenile hawksbill turtles on the Yaeyama Islands reported that wild turtles underwent short- or long-distance migrations (0.5 to $470 \mathrm{~km}$ ) (Kamezaki 1987, Kamezaki \& Hirate 1992). Thus, the habitat shifts demonstrated by the head-started turtle in our study seem to be natural behavior. In addition, Limpus (1992) reported that none of the wild hawksbill turtles relocated to another reef settled at the release point, while only one turtle was recaptured at the original place of release. This indicates that the wild juvenile hawksbill turtles may search for appropriate habitats when released at the other places. Therefore, habitat shifts by head-started turtles might indicate that they are searching for a more appropriate settlement habitat.

During the year of monitoring, with monitoring periods after the first and second releases combined, there was no change in the activity of the head-started turtle HH4 during diurnal periods and its inactivity during the night among the 5 time periods (Fig. 5b). This indicated that the turtle's diel activity rhythms were normal throughout a year after release. However, some signals were received during the nocturnal periods in the time Periods 2 and 3. We could, therefore, not determine whether the head-started turtle HH4 came to rest under coral due to the intermittent signal receptions.

\section{CONCLUSIONS}

Our results demonstrate that head-started hawksbill turtles have the ability to survive in the wild for a period of at least $7 \mathrm{mo}$ and can make feeding adaptations to adjust to their natural environment. Our study also found that head-started hawksbill turtles need pre-release training to use ridge structures during a period of rest. These findings provide constructive information for the implementation and improvement of head-start programs. However, the available postrelease behavioral and ecological data on head-started turtles is not sufficient to determine the effectiveness of a head-starting program. For example, the imprinting mechanism that guides turtles to their nesting beach and the migration ecology following release are still not fully understood (Shaver \& Wibbels 2007). A comparison between the release sites and nesting sites of mature female reared turtles which did not experience imprinting should be useful to improve our knowledge of the treatment of reared turtles and of the imprinting mechanism (Shaver 2005). In order to establish head-starting as an appropriate conservation tool and a successful reintroduction program, we need to continue turtle monitoring and to accumulate much more knowledge about head-started as well as wild turtles.

Acknowledgements. We acknowledge Drs. H. Mitamura, T. Yasuda, and K. Ichikawa and the staff of the Ishigaki Tropical Station, Seikai National Fisheries Research Institute and Yaeyama station, NCSE, for research assistance. We also thank 2 anonymous reviewers and Mr. Y. Kawabata for their comments to improve this manuscript. We express appreciation to Dr. Y. Ise at the University of Tokyo for indentifying the turtle prey samples. This study was conducted with the permission of the Okinawa Prefecture (Permission No. 16-19) to catch and handle the turtles. This study was partly supported by a Sasakawa Scientific Research Grant from The Japan Science Society (Grant no. 16-391M), a Grant-in-Aid for JSPS Fellows to J.O. (Grant no. 17-1976), and Kyoto University Global COE Program: Informatics Education and Research Center for Knowledge-Circulation Society.

\section{LITERATURE CITED}

Arendt MD, Lucy JA, Evans DA (2001) Diel and seasonal activity patterns of adult tautog, Tautoga onitis, in lower Chesapeake Bay, inferred from ultrasonic telemetry. Environ Biol Fishes 62:379-391

Avens L, Braun-McNeill J, Epperly S, Lohmann KJ (2003) Site fidelity and homing behavior in juvenile loggerhead sea turtles (Caretta Caretta). Mar Biol 143:211-220

Bartol SM, Musick JA, Lenhardardt M (1999) Auditory evoked potentials of the loggerhead sea turtles (Caretta caretta). Copeia 1999(3):836-840

Beck BB, Rapaport LG, Stanley Price MR, Wilson AC (1994) Reintroduction of captive-born animals. In: Olney PJS, Mace GM, Feistner ATC (eds) Creative conservation: interactive management of wild and captive animals. Chapman \& Hall, London, p 265-286

Bell CDL, Parsons J, Austin TJ, Broderick AC, Ebanks-Petrie G, Godley BJ (2005) Some of them came home: the Cayman Turtle Farm headstaring project for the green turtle Chelonia mydas. Oryx 39:137-148

Blumenthal JM, Austin TJ, Bothwell JB, Broderick AC and others (2009) Diving behavior and movements of juvenile hawksbill turtles Eretmochelys imbricata on a Caribbean coral reef. Coral Reefs 28:55-65

Brill RW, Balazs GH, Holland KN, Chang RKC, Sullivan S, George JC (1995) Daily movements, habitat use, and submergence intervals of normal and tumor-bearing juvenile green turtles (Chelonia mydas L.) with a foraging area in the Hawaiian Islands. J Exp Mar Biol Ecol 185:203-218

Diez CE, van Dam RP (2002) Habitat effect on hawksbill turtle growth rates on feeding grounds at Mona and Monito Islands, Puerto Rico. Mar Ecol Prog Ser 234:301-309

Fontaine C, Shaver DJ (2005) Head-starting the Kemp's ridley sea turtle, Lepidochelys kempii, at the NMFS Galveston laboratory, 1978-1992: a review. Chelonian Conserv Biol $4: 838-845$

Griffith B, Scott JM, Carpenter JW, Reed C (1989) Translocation as a species conservation tool: status and strategy. Science 245:477-480

> Houghton DR, Callow MJ, Hays GC (2003) Habitat utilization by juvenile hawksbill turtles (Eretmochelys imbricata, 
Linnaeus, 1766) around a shallow water coral reef. J Nat Hist 37:1269-1280

Huff JA (1989) Florida (USA) terminates 'headstart' program. Mar Turtle Newsl 46:1-2

IUCN (1998) Guidelines for re-introduction. IUCN/SSC Reintroduction Specialist Group, IUCN, Gland, Switzerland and Cambridge, UK

Kamezaki N (1987) Recapture of the hawksbill turtle, Eretmochelys imbricata (Linne), in the Yaeyama Islands, Ryukyu Archipelago. Galaxea 6:17-20

Kamezaki N, Hirate K (1992) Size composition and migratory cases of hawksbill turtles, Eretmochelys imbricata, inhabiting the waters of the Yaeyama Islands, Ryukyu Archipelago. Jpn J Herpetol 14:166-169

Kawabata Y, Okuyama J, Asami K, Yoseda K, Arai N (2008) The post-release process of establishing stable home ranges and diel movement patterns of hatchery-reared black-spot tuskfish Choerodon schoenleinii. J Fish Biol 73: 1770-1782

Kleiman DG (1989) Reintroduction of captive mammals for conservation. Bioscience 39:152-161

Klima EF, McVey JP (1995) Headstarting the Kemp's Ridley Turtle, Lepidochelys kempi. In: Bjomdal KA (eds) Biology and conservation of sea turtles, revised edn. Smithsonian Institution Press, Washington, DC, p 481-487

León YM, Bjorndal KA (2002) Selective feeding in the hawksbill turtle, an important predator in coral reef ecosystems. Mar Ecol Prog Ser 245:249-258

Limpus CJ (1992) The hawksbill turtle, Eretmochelys imbricata, in Queensland: population structure within a southern Great barrier reef feeding ground. Wildl Res 19: 489-506

Manzella SA, Caillouet CW Jr, Fontaine CT (1988) Kemp's Ridley, Lepidochelys kempi. Sea turtle head start tag recoveries: distribution, habitat, and method of recovery. Mar Fish Rev 50:24-32

Meylan A (1988) Spongivory in hawksbill turtles: a diet of glass. Science 239:393-395

> Mitamura H, Arai N, Mitsunaga Y, Yokota T, Takeuchi H, Tsuzaki T, Itani M (2005) Directed movements and diel burrow fidelity patterns of red tilefish Branchiostegus japonicus determined using ultrasonic telemetry. Fish Sci 71:491-498

Mortimer JA (1995) Headstarting as a management tool. In: Bjomdal KA (eds) Biology and conservation of sea turtles. Smithsonian Institution Press, Washington, DC, p 613-615

Nagelkerken I, Pors LPJJ, Hoetjes P (2003) Swimming behaviour and dispersal patterns of headstarted loggerhead turtles Caretta caretta. Aquat Ecol 37:183-190

Ridgway SH, Wever EG, McCormick JG, Palin J, Anderson JH (1969) Hearing in the giant sea turtle, Chelonia mydas. Proc Natl Acad Sci USA 64:884-890

Sato F, Madriasau BB (1991) Preliminary report on natural reproduction of hawksbill sea turtle in Palau. Mar Turtle Newsl 55:12-14

Seddon PJ, Armstrong DP, Maloney RF (2007) Developing the science of reintroduction biology. Conserv Biol 21:303-312

Editorial responsibility: Jeffrey Seminoff,

La Jolla, California, USA
Seminoff JA, Resendiz A, Nichols WJ (2002) Home range of green turtles Chelinia mydas at a coastal foraging area in the Gulf of California, Mexico. Mar Ecol Prog Ser 242: 253-265

Shaver DJ (1991) Feeding ecology of wild and head-started Kemp's ridley sea turtles in south Texas waters. J Herpetol 25:327-334

Shaver DJ (2005) Analysis of the Kemp's ridley imprinting and headstart project at Padre Island national seashore, Texas, 1978-88, with subsequent nesting and stranding records on the Texas coast. Chelonian Conserv Biol 4: 846-859

Shaver DJ, Wibbels T (2007) Head-starting the Kemp's ridley sea turtle. In: Plotkin PT (ed) Biology and conservation of ridley sea turtles. The Johns Hopkins University Press, Baltimore, MD, p 297-323

Stanley Price MR, Soorae PS (2003) Reintroductions: Whence and whither? Int Zoo Yearb 38:61-75

Storch S, Hays GC, Hillis-Starr Z, Wilson RP (2006) The behaviour of a hawksbill turtle data-logged during the passage of hurricane Georges through the Caribbean. Mar Freshw Behav Physiol 39:307-313

van Dam RP, Diez CE (1996) Diving behavior of immature hawksbills (Eretmochelys imbricata) in a Caribbean cliffwall habitat. Mar Biol 127:171-178

van Dam RP, Diez CE (1997a) Diving behavior of immature hawksbill turtles (Eretmochelys imbricata) in a Caribbean reef habitat. Coral Reefs 16:133-138

van Dam RP, Diez CE (1997b) Predation by hawksbill turtles on sponges at Mona Island, Puerto Rico. Proc 8th Int Coral Reef Symp 2: 1421-1426

> van Dam RP, Diez CE (1998) Home range of immature hawksbill turtles (Eretmochelys imbricata (Linnaeus)) at two Caribbean islands. J Exp Mar Biol Ecol 220:15-24

Werner SA, Landry AM Jr (1994) Feeding ecology of wild and head-started Kemp's ridley turtles (Lepidochelys kempii). In: Bjorndal KA, Bolten AB, Johnson DA, Eliazar PJ (eds) Proc 14th Ann Symp Sea Tur Biol Cons. NOAA Tech Mem NMFS-SEFC-351:163

Wibbels TR (1983) A transatlantic movement of a headstarted Kemp's ridley. Mar Turtle Newsl 24:15-16

Wibbels TR (1984) Orientation characteristics of immature Kemp's ridley sea turtles, Lepidochelys kempii. NOAA Tech Mem NMFS-SEFC-131

Wilson AC, Price MRS (1994) Reintroduction as a reason for captive breeding. In: Olney PJS, Mace GM, Feistner ATC (eds) Creative conservation: interactive management of wild and captive animals. Chapman \& Hall, London, p 243-264

> Yokota T, Mitamura H, Arai N, Masuda R and others (2006) Comparison of behavioral characteristics of hatcheryreared and wild red tilefish Branchiostegus japonicus released in Maizuru Bay by using acoustic telemetry. Fish Sci 72:520-529

Yoseda K, Shimizu T (2006) Technology development for spontaneous spawning, egg management and juvenile stocking in endangered sea turtles. Bull Jpn Soc Sci Fish 72:476-479 (in Japanese)

Submitted: June 25, 2009; Accepted: October 22, 2009

Proofs received from author(s): January 26, 2010 